\title{
Effects of Twenty-Four Weeks Training on Insulin Resistance Parameters and Metabolic Profiles in Adolescent Wrestlers
}

\author{
Mustafa GÜMÜŞ ${ }^{1}$, Taner BAYRAKTAROĞLU², İbrahim E. Pİ̧KİN ${ }^{3}$, Tevfik C. AKALIN ${ }^{1}$, Faruk YAMANER ${ }^{4}$ \\ ${ }^{1}$ Department of Physical Education and Sports Education, Physical Education and Sports School, Bulent Ecevit University, Zonguldak, Turkey \\ ${ }^{2}$ Department of Endocrinology, Medicine Faculty, Bulent Ecevit University, Zonguldak, Turkey \\ ${ }^{3}$ Department of Pediatrics, Medicine Faculty, Bulent Ecevit University, Zonguldak, Turkey \\ ${ }^{4}$ Department of Physical Education and Sports Education, Sports Science Faculty, Hitit University, Çorum, Turkey
}

\begin{abstract}
Aim: Obesity has become an increasing health concern in childhood and adolescence. We aimed to investigate the metabolic syndrome criteria in adolescent wrestlers and to investigate changes in insulin resistance and metabolic markers after 24 weeks of exercise program.

Material and Methods: Fifty wrestlers between the ages of 13 and 15 were enrolled to the study. Anthropometric and metabolic characteristics including age, body weight, height, body mass index (BMI), waist circumferences, systolic blood pressure, and diastolic blood pressure and metabolic syndrome criteria were obtained.

Results: After training program wrestlers' body mass index, total cholesterol, triglycerides and LDL- cholesterol values were not found statistically significant. Nonetheless, there was a convincing statistical decline in glucose, insulin, HOMA-IR and HDL- cholesterol average value. While wrestlers' body mass index, total cholesterol, triglycerides and LDL- cholesterol average was remained same after the training program, fasting glucose and HOMA-IR values in terms of insulin resistance have decreased significantly.

Conclusion: While completing the period of growth and development, the wrestling training program of adolescent wrestlers has positive effects on metabolism and insulin resistance. It is revealed that the training program have favorable effects on metabolism and insulin resistance.
\end{abstract}

Key Words: Adolescence, Wrestlers, Metabolic syndrome, Insulin resistance, HOMA-IR

\section{Adolesan Güreşçilerde Yirmi Dört Haftalık Egzersizin İnsülin Direnci Parametreleri ve Metabolik Profiller Üzerine Etkileri}

\begin{abstract}
ÖZET
Amaç: Obezite, çocukluk ve ergenlik döneminde artan bir sağlık sorunu haline geldi. Çalışmamızda, ergen güreşçilerinde metabolik sendrom kriterlerini belirleyerek 24 haftalık egzersiz programından sonra insülin direncini ve metabolik göstergelerin değişikliklerini araştırmayı amaçladık.

Gereç ve Yöntemler: Genç - yetişkin 13-15 yaş arası 50 güreşçi çalışmaya alındı. Yaş, vücut ağırlığı, boy, vücut kütle indeksi (BKİ), bel çevresi, sistolik kan basınc1, diastolik kan basıncı ve metabolik sendrom kriterleri dahil olmak üzere antropometrik ve metabolik özellikler elde edildi.

Bulgular: Egzersiz programından sonra güreşçilerin vücut kütle indeksi, total kolesterol, trigliserid ve LDL kolesterol değerlerindeki değişkenlik istatistiksel olarak anlamlı bulunmamıştır ( $\mathrm{p}<0.05)$. Bununla birlikte, glikoz, insülin, HOMA-IR ve HDL-kolesterol ortalama değerinde istatistiksel anlamlılıkta düşüklük saptandı $(\mathrm{p}<0.05)$.

Sonuç: Büyüme ve gelişme dönemini tamamlarken adölesan güreşçiler yaptıkları güreş eğitim programının metabolizma ve insülin direnci üzerinde olumlu etkileri olduğu ortaya çıkmaktadır.
\end{abstract}

Anahtar Sözcükler: Adölesan, Güreşçi, Metabolic Sendrom, İnsülin Direnci, HOMA-IR

DOI: $10.25048 /$ tjdo.2017.21 


\section{INTRODUCTION}

Obesity has become an increasing health concern in childhood and adolescence. Throughout the world, especially in underdeveloped and developing countries, it is estimated that approximately 170 million children are overweight (1). The cardiovascular risk factors such as; metabolic syndrome, high blood pressure, diabetes mellitus, dyslipidemia, insulin resistance increase in parallel with the increase in weight. The insulin resistance of obese children has been associated with obesity in adulthood, metabolic syndrome and type 2 diabetes development (2). In long term tracking researches it is discovered that the prevalence of metabolic syndrome is significantly high by $34.9 \%$ in obese and insulin resistant individuals whereas it is $24.3 \%$ in obese and insulin sensitive individuals (3). The production of proinflammatory cytokine, increase in free fatty acids, decreased tissue sensitivity to insulin, the need to adaptive insulin increase to maintain glycemic balance (4), the increase of fasting glucose, the emergence of pre diabetes and type 2 diabetes are among the prominent causes and effects of obesity (5-7).

The physiological stress associated with competitive wrestling, nutrient/fluid restriction, and body mass fluctuations has been speculated to slow the somatic growth of adolescent wrestlers $(8,9)$. Somatic growth and biological maturation are dynamic processes regulated by a variety of genetic and environmental factors. Genetic predisposition to growth can be fully expressed only under favorable environmental conditions. Major environmental factors that may alter somatic growth are intensive physical exercise and stress. The impact of stress and intensive physical exercise on growth depends on combined effects of intensity, frequency, and duration of exercise (10). Physical exercise acts as a stress to the endocrine system. Particularly with intensive training, such as in competitive sporting activities, significant changes in circulating hormonal levels can occur $(11,12$.).

In our study, we aim to investigate insulin resistance and the variance in metabolic indicators in adolescent wrestlers by defining metabolic syndrome criteria after 24-week exercises program.

\section{MATERIALS and METHODS}

Fifty adolescent male wrestlers aged between 13-15 years were selected. They were active at competitive level (participating in regional and/or national competitions) and were from five different wrestling schools (Çorum, Tokat, Yozgat, Sivas, Amasya) affiliated by the Turkish Wrestling Federation that have well-developed training program for children in wrestling. The wrestlers had been training for one to two years prior to study at least 5 days a week 2 hour a day. The study was approved by the local ethics committee of Bulent Ecevit University Faculty of Medicine. Written informed consent was obtained from each participant and one of the parents.

The wrestlers' training commenced in 2012 and the subjects were examined after wrestling season ended. Data about the anthropometric and metabolic characteristics including age, body weight, height, body mass index (BMI), waist circumferences, systolic blood pressure, and diastolic blood pressure were obtained. The control group was composed of 21 sedentary and healthy male volunteers with an age range of 13-15. These boys were training not more than $2 \mathrm{~h} / \mathrm{wk}$.

The body height of the subjects was measured by a metal scale with a $0.1 \mathrm{~cm}$ sensitivity, and the body weight measurement was taken by a digital weight with a $0.1 \mathrm{~kg}$ sensitivity. Body mass index was calculated as weight $(\mathrm{kg})$ divided by the square of height $(\mathrm{m})$. The current criteria of metabolic syndrome were detected in accordance with wrestlers' waist circumference, fasting blood glucose, blood pressure, HDLcholesterol and triglycerides values (13-14). Systolic blood pressure and diastolic blood pressure percentiles were determined in terms of paint percentile. The 95 and over percentile value of those with systolic and diastolic blood pressure was defined as hypertension (15-19).

Anthropometric and metabolic parameters are investigated before and after the workout. For this purpose, body mass index, the variance in insulin resistance parameters (glucose, insulin, HOMA-IR) and lipid parameters (total cholesterol, triglycerides, HDL- cholesterol, LDL- cholesterol) were analyzed. HOMA-IR value "homeostasis model assessment (HOMA)-insulin resistance" was calculated by the formula HOMA-IR $=$ fasting plasma glucose $(\mathrm{mg} / \mathrm{dl}) \times$ fasting insulin $(\mu \mathrm{U} / \mathrm{mL}) / 405(20-21)$. The decline in beta-cell function (\%b) according to the calculations found by Glucose $\mathrm{mmol} / 1$ insulin, $\mathrm{mU} / \mathrm{ml}$, C-peptide $\mathrm{mmol} / 1$ unit's conversion gives information about insulin resistance (IR).

All data were collected at the Medical Faculty laboratory at Bulent Ecevit University, Zonguldak. Blood samples were withdrawn into heparinized tubes from a cubital vein after overnight fasting and immediately stored in ice. Plasma was separated from cells by centrifugation at 3000 rpm for $10 \mathrm{~min}$ and the plasma samples were stored at $-80{ }^{\circ} \mathrm{C}$ until analysis. Analyses of serum glucose, insulin, total cholesterol, triglyceride, HDL-cholesterol and LDLcholesterol were determined by an automated chemistry analyzer (Spectrophotometric enzymatic method, Roche Integra 800) using commercial kits.

\section{Statistical Analysis}

Statistical analysis was performed with SPSS 18.0 software (SPSS Inc., Chicago, IL, USA). Continuous variables were 
expressed as mean \pm standard error of mean and median (minimum-maximum), categorical variables as frequency and percent in wrestlers and controls. Continuous variables were compared with the Independent Sample t test or MannWhitney $U$ test and categorical variables were compared using Pearson's Chi-square test for two groups. Baseline and after training period, BMI, HOMA-IR and lipid parameters were compared with the Paired Sample $t$ test. Categorical variables were compared using Pearson's Chi-square test for two groups. A p value of less than 0.05 was considered statistically significant for all tests.

\section{RESULTS}

It was figured out that adolescent wrestlers aged 13-15 have 1-5 years for active sport, their waist circumferences were average $71.50 \pm 8.02$, body mass indices were $19.97 \pm 2.96 \mathrm{~kg} /$ $\mathrm{m} 2$ and mean systolic/diastolic blood pressures were $116.68 \pm 13.65$ / 81.0 $\pm 10.27 \mathrm{mmHg}$ (Table 1).

Statistical differences were not verified in terms of age, height, weight, waist circumference, body mass index and diastolic blood pressure between wrestlers and control group. Nevertheless, it was found out that the average systolic blood pressure was higher in wrestlers $(\mathrm{p}<0.05)$ (Table 1).

According to metabolic syndrome criteria (IDF) waist circumference and hyperglycemia were not tracked. Besides it was determined that triglycerides were high in one case $(1 / 50)$, HDL- cholesterol was low $(\leq 40 \mathrm{mg} / \mathrm{dl}) 18 / 50$ and blood pressure levels were high $\geq 130 \mathrm{mmHg}$ or diastolic $>90 \mathrm{mmHg}$ ) 9/50. Any three criteria that would meet metabolic syndrome were not discovered. Therefore, subgroup analysis has not been carried out.

In the control group, a case of high waist circumference, high fasting glucose and hypertriglyceridemia were not observed. According to the criteria of metabolic syndrome there was not a case that met metabolic syndrome diagnosis in the control group. Hypertension in this group was revealed by systolic and diastolic blood pressure percentile in accordance with height percentile, approximately $4.7 \%$. According to height percentile, hypertensive ratio in wrestlers were calculated in a case of systolic and diastolic blood pressure percentile being over 95 percentiles, approximately $16.0 \%$.

After training program, the variations of the wrestlers' body mass index, total cholesterol, triglycerides and variance in LDL- cholesterol values were not found statistically significant $(p>0.05)$. Nonetheless, there were a convincing statistical decline in glucose, insulin, HOMA-IR and HDLcholesterol average value $(\mathrm{p}<0.05)$ (Table 3$)$. An increase in HDL-cholesterol values were tracked regarding 14(28.0\%) of the cases. Although the average values of fasting blood glucose $(\geq 100 \mathrm{mg} / \mathrm{dl})$ and triglycerides values $(>150 \mathrm{mg} / \mathrm{dl})$

Table 1: Demographic and anthropometric parameters regarding wrestlers.

\begin{tabular}{|c|c|c|c|c|c|c|c|c|c|}
\hline \multirow{2}{*}{$\begin{array}{l}\text { Demographic } \\
\text { and } \\
\text { anthropometric } \\
\text { parameters }\end{array}$} & \multicolumn{4}{|c|}{$\begin{array}{l}\text { Wrestlers } \\
(\mathrm{n}=50)\end{array}$} & \multicolumn{4}{|c|}{$\begin{array}{l}\text { Control group } \\
\qquad(\mathrm{n}=21)\end{array}$} & \multirow{2}{*}{$\mathbf{p}$} \\
\hline & Minimum & Maximum & Average & $\begin{array}{c}\text { Std. } \\
\text { Division }\end{array}$ & Minimum & Maximum & Average & $\begin{array}{c}\text { Std. } \\
\text { Division }\end{array}$ & \\
\hline Age (year) & 13 & 15 & 14,39 & 0,62 & 13 & 15 & 14,10 & 0,831 & 0,103 \\
\hline $\begin{array}{l}\text { Active sport } \\
\text { duration (year) }\end{array}$ & 1,00 & 5,00 & 1,94 & 0,87 & - & - & - & - & - \\
\hline Height(m) & 1,34 & 1,72 & 1,51 & 0,11 & 1,30 & 1,64 & 1.52 & 0,095 & 0,142 \\
\hline Weight (kg) & 30,00 & 75,00 & 44,96 & 11,78 & 33,0 & 73,00 & 45,43 & 10.82 & 0,233 \\
\hline $\begin{array}{l}\text { Waist } \\
\text { circumference } \\
(\mathrm{cm})\end{array}$ & 61,00 & 98,00 & 71,50 & 8,02 & 61,00 & 87,00 & 68,86 & 6,90 & 0,192 \\
\hline $\begin{array}{l}\text { Body mass index } \\
\left(\mathrm{kg} / \mathrm{m}^{2}\right)\end{array}$ & 15,53 & 29,24 & 19,97 & 2,96 & 16,00 & 27,00 & 19,54 & 3,03 & 0,582 \\
\hline $\begin{array}{l}\text { Systolic blood } \\
\text { pressure } \\
(\mathrm{mmHg})\end{array}$ & 91,00 & 155,00 & 116,68 & 13,65 & 94,00 & 129,00 & 110,43 & 7,94 & $0,019^{\star}$ \\
\hline $\begin{array}{l}\text { Diastolic } \\
\text { blood pressure } \\
\text { (mmHg) }\end{array}$ & 42,00 & 98,00 & 68,74 & 11,34 & 50,00 & 89,00 & 64,48 & 8,90 & 0,130 \\
\hline
\end{tabular}


in metabolic syndrome diagnostic criteria were significantly variance, they were within normal limits (Table 2). While three of the 46 cases having HDL-cholesterol below $40 \mathrm{mg} / \mathrm{dl}$ were detected to fall below $40 \mathrm{mg} / \mathrm{dl}$ after training program, the values belonging two of the four cases rose over $40 \mathrm{mg} / \mathrm{dl}$ $(\mathrm{x} 2=7.729, \mathrm{p}=0.045)$. Moreover, average HDL-k cholesterol values $(55,04 \pm 11,10 \mathrm{mg} / \mathrm{dl}$ and $52,34 \pm 10,65)$ remained higher than metabolic syndrome criteria (for males $<40 \mathrm{mg}$ / dl) before and after the training course (Table 3 ).

\section{DISCUSSION}

One of the main factors related to obesity and being overweight, along with insulin resistance, is a sedentary lifestyle in childhood and adolescence (6). A study by ReyLópez et al. (22) highlighted the time that children spent watching television as a determining factor in weight gain, for which physical exercise was the indicated therapeutic approach. Systematic reviews with meta-analyses showed the beneficial effects of exercise on lipid profiles $(23,24)$, blood pressure (25), glucose, and insulin levels (26) for children and adolescents who are overweight or obese. However, evidence of the effect of exercise on glucose metabolism (26) focused only on aerobic exercise, although resistance training is also able to show different benefits for children and adolescents (27) and higher levels of muscular fitness are inversely associated with cardio metabolic outcomes, such as insulin resistance and systemic inflammation in children and adolescents (28).

After the study determined in regard to demographic, anthropometric and metabolic changes belonging to adolescent wrestlers, these data were compared with the control group. The age, weight, height, body mass index, waist circumference and diastolic blood pressure average of adolescent wrestlers were not different from the control group. The rate of the wrestlers with higher systolic blood pressures were found higher than controls. It has been

Table 2: Distributions of criteria for metabolic syndrome

\begin{tabular}{llcccc}
\hline & \multirow{2}{*}{ Metabolic Syndrome Criteria } & \multicolumn{2}{c}{$\begin{array}{c}\text { Wrestlers } \\
(\mathrm{n}=50)\end{array}$} & \multicolumn{2}{c}{$\begin{array}{c}\text { Control group } \\
(\mathrm{n}=21)\end{array}$} \\
\cline { 2 - 6 } & & $\mathbf{n}$ & $\mathbf{\%}$ & $\mathbf{n}$ & $\%$ \\
\hline Waist circumference size & For males $\geq 94 \mathrm{~cm}$ & 1 & 2.0 & 0 & 0.0 \\
\hline Fasting glucose levels & $\geq 100 \mathrm{mg} / \mathrm{dl}$ or Type 2 Diabetes diagnosis & 0 & 0.0 & 0 & 0.0 \\
\hline \multirow{3}{*}{ Blood pressure } & Systolic blood pressure $\geq 130 \mathrm{mmHg}$ or & 9 & 18.0 & 0 & 0.0 \\
\cline { 2 - 6 } & Diastolic blood pressure $\geq 85 \mathrm{mmHg}$ or & 2 & 4.0 & 1 & 4.7 \\
\cline { 2 - 6 } & Hypertension diagnosis and treatment & 0 & 0.0 & 0 & 0.0 \\
\hline HDL-k levels & $<40 \mathrm{mg} /$ dl or lipid disorder under treatment & 4 & 8.0 & 2 & 9.5 \\
\hline Triglycerides levels & $>150 \mathrm{mg} /$ dl or lipid disorder under treatment & 1 & 2.0 & 0 & 0.0 \\
\hline
\end{tabular}

HDL: High density lipoprotein.

Table 3: Metabolic indicators of wrestlers before and after the training program, the variety in insulin resistance parameters.

\begin{tabular}{|c|c|c|c|}
\hline $\begin{array}{l}\text { Metabolic and Insulin Resistance } \\
\text { Parameters }\end{array}$ & Beginning & $\begin{array}{c}\text { After } 24 \text { Week Training } \\
\text { Program }\end{array}$ & $\mathbf{p}$ \\
\hline Body mass index $(\mathrm{Kg} / \mathrm{m} 2 \pm \mathrm{SD})$ & $19,98 \pm 2,96$ & $19,97 \pm 2,96$ & 0,322 \\
\hline Glucose $(\mathrm{mg} / \mathrm{dl} \pm \mathrm{SD})$ & $83,48 \pm 8,70$ & $66,38 \pm 10,23$ & $0,001^{\star}$ \\
\hline Insulin $(\mathrm{mmol} / \mathrm{L} \pm \mathrm{SD})$ & $6,24 \pm 3,21$ & $5,08 \pm 2,79$ & $0,015^{\star}$ \\
\hline HOMA-IR $( \pm S D)$ & $1,30 \pm 0,71$ & $0,86 \pm 0,53$ & $0,001^{\star}$ \\
\hline Total cholesterol (mg/dl $\pm \mathrm{SD})$ & $144,6 \pm 23,5$ & $141,6 \pm 22,62$ & 0,183 \\
\hline Triglycerides (mg/dl $\pm \mathrm{SD})$ & $64,24 \pm 27,12$ & $73,84 \pm 44,81$ & 0,178 \\
\hline LDL-Cholesterol(mg/dl $\pm S D)$ & $79,92 \pm 21,68$ & $79,06 \pm 19,54$ & 0,660 \\
\hline HDL-Cholesterol(mg/dl $\pm \mathrm{SD})$ & $55,04 \pm 11,10$ & $52,34 \pm 10,65$ & $0,030^{*}$ \\
\hline
\end{tabular}

SD: Standard deviation, HOMA-IR: Homeostasis model assessment - insulin resistance, LDL: Low density lipoprotein, HDL: High density lipoprotein. ${ }^{*} \mathrm{p}<0.05$ 
supposed that the intensity of the workout and the training program have affected this outcome. Metabolic syndrome criteria before 24-week exercise in adolescent wrestlers were examined in our study. Any case identified with metabolic syndrome was not obtained, that is three criteria were not found simultaneously in a subject. There was not any occurrence concerning especially fasting blood glucose and waist circumference. High levels of triglycerides was tracked in one occurrence and there were four case indicating low levels of HDL-cholesterol. Interestingly, 11 cases (22.0\%) were obtained that met blood pressure criteria.

According to metabolic syndrome criteria and height percentile and blood pressure percentile, the cases with high blood pressure were not urgent that require further intervention regarding hypertension. Any case was not tracked that would meet syndrome definition concerning metabolic syndrome criteria in adolescent wrestlers and control groups. While there were cases holding one or two criteria, any case with three criteria were not detected. It shows that performing metabolic syndrome criteria among healthy control groups or adolescent wrestlers is inappropriate. However, high blood pressure of metabolic syndrome criteria in wrestlers is remarkable. The findings should be evaluated for further investigation and treatment if required.

It is suggested that the assessment of blood pressure in adolescents be carried out in accordance with height and blood pressure percentile $(15-19,29)$. It is reported that the hypertension prevalence rate in adolescents is $3.2 \%-34$; prehypertension prevalence is $3.6-15.7 \%$. Also, the prevalence combination of prehypertension and hypertension is revealed to be over $30 \%$ (30-32). Values above 95 percentiles are considered hypertension in adolescents.

Although among metabolic syndrome criteria 11 (22.0\%) occurrence that meets high blood pressure criterion were revealed, a case which is low in terms of percentile values defined for adolescents but having significant high blood pressure was identified. The reason behind this high rate can be explained by investigating some risk factors such as nutrition, salt content, familial hypertension as well as wrestlers' exercise and training capabilities.

Rapid weight loss $4 \%$ in adolescent freestyle wrestlers was informed to lead to a significant decrease in anthropometric measurements, insulin resistance, HOMA-IR and leptin values. $(33,34)$. In our study, a significant decline $(\mathrm{p}<0.05)$ in fasting glucose, fasting insulin and HOMA-IR values was obtained though body mass index in adolescent wrestlers remained same after 24-week exercise.

The relationship between serum HDL-C levels and coronary artery heart disease in human beings has been investigated with various aspects by many researchers and many beneficial results have been provided about this subject. Along with the factors such as nourishment with highcarbohydrate diet reducing HDL-C levels, hemodialysis, progesterone, androgens, beta blockers, cigarette smoking, diabetes mellitus, obesity, the factors as well as exercises, alcohol, estrogen, weight loss raising HDL-C levels have long become a subject of researchers (35). Along with studies that present HDL-cholesterol in male athletes usually increases with exercise, it is also true that these levels do not change. There is even a study revealing HDL- cholesterol decreases associated with the period of the exercise. Enger et al. observed a decline in total cholesterol, triglycerides and LDL cholesterol and a rise in HDL cholesterol after intensive skiing (36-38). It is confirmed that while the exercise raises HDL-C level which is protective in terms of coroner heart disease among the youth, it reduces LDL-I levels that is a vital risk factor among elderly (39).

In 1992 study, Hubinger et al. 15 sedentary males were put to exercise on bicycle ergometer that lasted 30 minutes at $50 \mathrm{rpm}$ and maximal heart rate at $60 \%$. According to the information obtained from the measurements after the exercises at serum HDL-C levels, a significant increase was observed and it was followed by a decrease 15 minutes after the exercise. Within other parameters, triglycerides levels enhanced while no variance was tracked at total cholesterol and LDL- cholesterol rate (40). In consequence of maximal bicycle ergometer test, according to the results of three measurements right after the exercise and 15 minutes after the exercise, serum HDL-cholesterol levels right after the exercise expanded statistically significant $(\mathrm{p}<0,05)$. Nevertheless, an insignificant drop was recognized at LDL cholesterol levels ( $p>0,05)$. Total cholesterol and triglyceride levels increased after exercise but not statistically significant $(\mathrm{p}>0,05)(41)$.

Tamer and his friends created four groups of 10 people to investigate the effects of different aerobic training programs on serum hormones, blood lipids and body fat percentage. Group A was put to continuous jogging program, group B performed intermittent jogging program, group C practiced short intermittent jogging program and lastly group D was determined as the control group. At the end of the study, while a decrease in cholesterol levels in A, B, C groups' subjects were examined, there were not a significant difference among subjects regarding HDL-cholesterol. Besides they revealed a decline at LDL-cholesterol levels of the subjects. The increase in HDL-cholesterol was interpreted statistically insignificant. Various researchers informed that HDL-cholesterol was affected positively by the endurance exercise whereas cholesterol, triglycerides and LDL-cholesterol was affected negatively. They found a positive relation between maximal V02, total cholesterol and 
HDL-cholesterol, a negative relation between triglycerides and LDL-cholesterol, a positive relation between anaerobic power and HDL-cholesterol, and negative between anaerobic power and triglycerides (42).

All in all, according to the healthy controls, systolic blood pressures of those who wrestle in adolescence were found significantly high. It is revealed that the training program have favorable effects on metabolism and insulin resistance. While wrestlers' body mass index, total cholesterol, triglycerides and LDL- cholesterol average was remained same after the training program, fasting glucose and HOMA-IR values in terms of insulin resistance have decreased significantly. Although HDL-k average decreased at the end of one period among wrestlers, they remained over the limit that was regarded risky. The syndrome maybe requires redefining for this group after the standardization of metabolic syndrome among adolescent wrestlers.

\section{REFERENCES}

1. Population-Based Approaches to Childhood Obesity Prevention. Word Health Organization Press, Geneva, Switzerland. 2012. http://www.who.int/dietphysicalactivity/ childhood/ WHO_new_childhoodobesity PREVENTION_27nov_HR_PRINT_OK.pdf. Accessed date 25.10.2017.

2. Liang Y, Hou D, Zhao X, Wang L, Hu Y, Liu J, Cheng H, Yang P, Shan X, Yan Y, Cruickshank JK, Mi J,. Childhood obesity affects adult metabolic syndrome and diabetes. Endocrine 2015;60:87-92.

3. Zhang, H., Zhang, T., Li, S., Li, Y., Hussain, A., Fernandez, C., et al.. long-termimpact of childhood adiposity on adult metabolic syndrome is modified by insulin resistance: the bogalusa heart study. Sci Rep 2015;5:17885.

4. Ten, S.,Mclaren, N..Insulin resistance syndrome in children. J Clin Endocrinol Metab 2004;89 (6):2526-2539.

5. American Diabetes Association. Standards of medical care in diabetes. Diabetes Care 2017;40(Sup.1), S1-S135.

6. Rennie, K., Johnson, L., Jebb, S.. Behavioural determinants of obesity. Best Pract Res Clin Endocrinol Metab 2005;19 (3):343-358.

7. Marson EC1, Delevatti RS2, Prado AK3, Netto N4, Kruel LF. Effects of aerobic, resistance, and combined exercise training on insulin resistance markers in overweight or obese children and adolescents: A systematic review and meta-analysis. Prev Med. 2016;93:211-218.

8. McMurray, RG., Hackney, AC. Endocrine responses to exercise and training. Exercise and sports science. Edited by William E Garrett, Jr., And Donald T Kirkendall. Lippincott Williams \& Wilkins, Philadelphia 142-143, 2000.
9. Roemmich, JN. Growth, Maturation and Hormonal Changes During Puberty: Influence of Sport Training, in The Endocrine System in Sports and Exercise (eds W. J. Kraemer and A. D. Rogol). Blackwell Publishing Ltd, Oxford, UK. doi: 10.1002/9780470757826.ch34, 2008.

10. Georgopoulos, NA., Roupas, ND., Theodoropoulou, A., Tsekouras, A., Vagenakis, AG., Markou, KB. (). The influence of intensive physical training on growth and pubertal development in athletes. Ann. N.Y. Acad. Sci, 2010;1205:3944.

11. Daly, RM., Rich, PA., Klein, R., and Bass, SL. Short stature in competitive prepubertal and early pubertal male gymnasts: the result of selection bias or intense training? J Pediatr, 2000;137:510-516.

12. Hackney AC, Sinning WE, Bruot BC. Reproductive hormonal profiles of endurance-trained and untrained males. Med Sci Sports Exerc, 1988;20(1): 60-65.

13. National Cholesterol Education Program (NCEP) Expert Panel on Detection, Evaluation, and Treatment of High Blood Cholesterol in Adults (Adult Treatment Panel III). Third Report of the National Cholesterol Education Program (NCEP) Expert Panel on detection, evaluation, and treatment of high blood cholesterol in adults (adult treatment panel III) final report. Circulation 2002; 106: 3143-3421.

14. Alberti KG, Zimmet P and Shaw J. Metabolic syndrome - a new world-wide definition. A Consensus Statement from the International Diabetes Federation. Diabet Med 2006; 23: 469480.

15. Lurbe E, Cifkova R, Cruickshank JK, Dillon MJ, Ferreira I, Invitti C, Kuznetsova T, Laurent S, Mancia G, MoralesOlivas F, Rascher W, Redon J, Schaefer F, Seeman T, Stergiou G, Wühl E, Zanchetti A; European Society of Hypertension. Management of high blood pressure in children and adolescents: recommendations of the European Society of Hypertension. J Hypertens 2009; 27:1719-1742.

16. Türk Kardiyoloji Derneği Ulusal Hipertansiyon Tedavi ve Takip Kılavuzu. 5. Özel Hasta Grupları. Çocukluk ve Adolesan Çağ1 Hipertansiyonu. 1999. https://www.tkd.org.tr/kilavuz/ k03.htm, https://www.tkd.org.tr/kilavuz/k03/5_11453. htm?wbnum=1109. Erişim 22.10.2017.

17. U.S. Department of Health and Human Services National Institutes of Health National Heart, Lung, and Blood Institute. The Fourth Report On the Diagnosis, Evaluation, And Treatment of High Blood Pressure in Children and Adolescents NIH Publication No. 05-5267 Originally printed September 1996 (96-3790) Revised May 2005. https://www.nhlbi.nih. gov/files/docs/resources/heart/hbp_ped.pdf Accessed date 22.10.2017.

18. Olcay N, Hülya G, Andrzej F. ve ark. Türk çocuklarında vücut ağırlığı, boy uzunluğu, baş çevresi ve vücut kitle indeksi referans değerleri. Çocuk Sağlığı ve Hastalıkları Dergisi 2008; 51: 1-14. 
19. Yoldemir ŞA, Yoldemir B. Adolesan Kan Basıncı Yüksekliğine Yaklaşım. Türkiye Aile Hekimlği Dergisi 2015; 6(3):96-107.

20. Matthews DR, Hosker JP, Rudenski AS, Naylor BA, Treacher DF, Turner RC. Homeostasis model assessment: insulin resistance and beta-cell function from fasting plasma glucose and insulin concentrations in man. Diabetologia. 1985;28(7):412-19.

21. Wallace TM, Levy JC, Matthews DR. Use and abuse of HOMA modeling. Diabetes Care. 2004;27(6):1487-95.

22. Rey-López JP, Vicente-Rodríguez G, Biosca M, Moreno LA. Sedentary behaviour and obesity development in children and adolescents. Nutr Metab Cardiovasc Dis 2008;18 (3):242-251.

23. Kelley G, Kelley K. Aerobic exercise and lipids and lipoproteins in children and adolescents:a meta-analysis of randomized controlled trials Atherosclerosis. 2007; 191(2): 447-453.

24. Karacabey, K. The effect of exercise on leptin, insulin, cortisol and lipid profiles in obese children. J. Int. Med. Res. 2009;37 (5):1472-8.

25. Garcia-hermos A. Saavendr, J.M., Escalante, I., Effects of exercise on resting blood pressure in obese children: ametaanalysis of randomized controlled trials. Obes Rev 2013;14 (11): 919-928.

26. Garcia-Hermoso A, Saavendra JM, Escalante I, SanchezLopez M, Martinez-Viscaino V. Aerobic exercise reduces insulin resistance markers in obese youth: a meta-analysis of randomized controlled trials. Eur J Endocrinol 2014;171 (4):R163-R171.

27. Faigenbaum, AD., Myer GD. Resistance training among young athletes: safety, efficacy and injury prevention effects. Br J Sports Med 2010;44 (1):56-63.

28. Artero EE, Lee DC, Lavie CJ, España-Romero V, Sui X, Church TS, Blair SN. Effects of muscular strength on cardiovascular risk factors and prognosis. J. Cardiopulm. Rehabil. Prev. 2012;32 (6):351-358.

29. Lurbe E, Agabiti-Rosei E, Cruickshank JK, Dominiczak A, Erdine S, Hirth A, Invitti C, Litwin M, Mancia G, Pall D, Rascher W, Redon J, Schaefer F, Seeman T, Sinha M, Stabouli S, Webb NJ, Wühl E, Zanchetti A. 2016 European Society of Hypertension guidelines for themanagement of high blood pressure in children andadolescents.. J. Hypertens. 2016; 34(10): 1887-920.
30. Hansen ML, Gunn PW, Kaelber DC. Underdiagnosis of hypertension in children and adolescents. JAMA. 2007; 298(8):874-9.

31. McNiece KL, Poffenbarger TS, Turner JL, Franco KD, Sorof JM, Portman RJ. Prevalence of hypertension and prehypertension among adolescents.J Pediatr. 2007; 150(6):640-4.

32. Falkner B. Hypertension in children and adolescents: epidemiology and natural history. Pediatr Nephrol. 2010 Jul; 25(7): 1219-1224.

33. Mohammad T1, Farzad N, Tagie GM, Ranjbar K. The impact of rapid weight loss on the leptin, adiponectin levels, and insulin resistance among adult free style wrestlers. J Sports Med Phys Fitness. 2015;55(7-8):805-12.

34. Talaei M1, Nazem F2, Ranjbar K3. The impact of rapid weight loss (4\%) on leptin, adiponectin, and insulin resistance in elite adult free style wrestlers. J Sports Med Phys Fitness. 2017;57(4):434-440.

35. Criqui Mh. Epidemiology of atherosclerosis: an update overview. Am. J. Cardiol, 1986:57:18-23.

36. Berg A, John J, Baumstalk M. Change on HDL-C subfractions after a single extended episode of physical exercise. Atherosclerosis. 1983;47:231-40.

37. Cullinane E. Lararus B, Thompson PD. Acute effect of a single exercise session on serum lipids in untrained men. Clin. Chim. Arta. 1981;109:241-4.

38. Enger CS, Herbjrnsen J, Fretland A. HDL-C and physical activity: The influence of physical exercise age and smoking on HDL-C and HDL-C/ total kolestrol ratio. Scand J. Clin. Lab. Invest. 1997;37:251-255,.

39. Yalaz G, Kayatekin BM, Güvel H, Derman S, Gönerçi S, Açıkgöz 0, Semin I, Kandemir F. Erkekte düzenli egzersizin lipid -lipoprotein profiline etkisi, Spor Hekimliği Dergisi, 1996;31: 107-114.

40. Hubinger LM, Mackinnon LT. The acute effects of $30 \mathrm{~min}$. of moderate exercise on high density lipoprott1 cholesterol in untrained men. Eur.J. Appl. Physlol, 1992;65(6) 555-60.

41. Özhan E, Hizmetli S, Özhan F, Bakır B. Erkek Sporcularda Egzersizin Kan Lipoproteinlerine Etkisi. C. Ü. Tıp Fakültesi Dergisi 2000;22 (2): 88 - 92.

42. Tamer,K ; Farklı aerobik antrenman programlarının seks hormonları, kan lipidleri ve vücut yağ yüzdesi üzerine etkisi. Bed. Eğt. Spor Bil. Der. 1996;1(1) :1-11. 


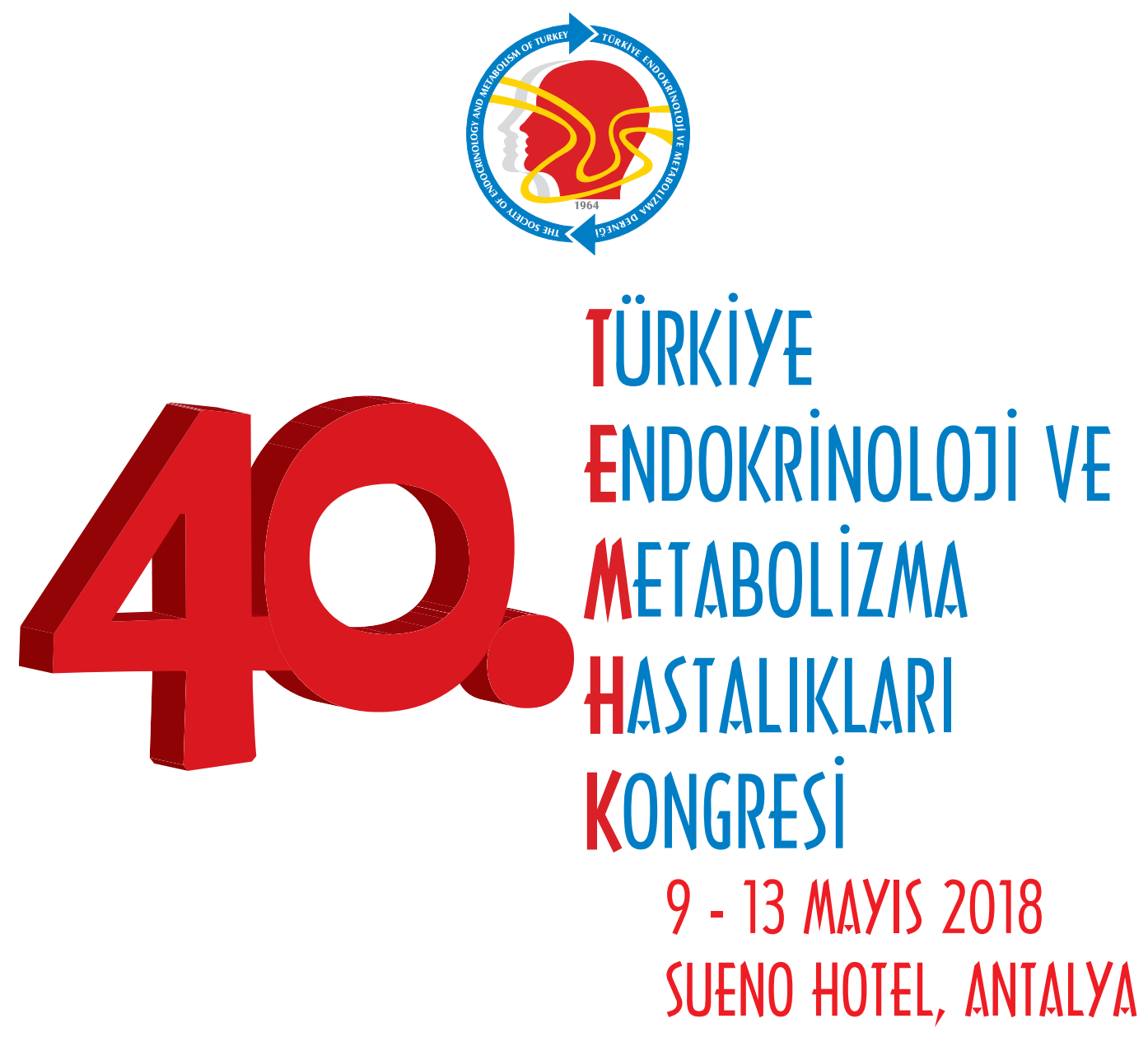

BiLIMSEL SEKREIERYA

Prof. Dr. Ilthan Yetkin, Prof. Dr. Reyhan Ersoy Türkiye Endokrinoloji ve Metabolizma Derneği Messutiyet Cad. Ali Bey Apt. 29/12 · Kzzlay / ANKARA

I : 0.3124252072 F : 0.3124252098 president@temd.org.tr www.temd.org.tr

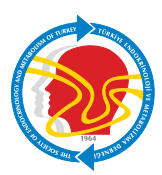

www.temhk2018.org 